\title{
Development and assessment of an erosion and landslide predictive model for the coastal region of the State of São Paulo, Brazil
}

\author{
Fabrício Bau DALMAS ${ }^{1}$, Fábio Rodrigo de OLIVEIRA², Isis Sacramento da SILVA ${ }^{3}$, Alex Joci dos \\ SANTOS $^{3}$, Antonio Conceição PARANHOS FILHO ${ }^{4}$ \& Arlei Benedito MACEDO ${ }^{1}$
}

1 Instituto de Geociências, Universidade de São Paulo. Rua do Lago, 562, Cidade Universitária, Butantã, CEP 05508-080, São Paulo, SP, Brasil. E-mail: fbdalmas@gmail.com, abmacedo@usp.br.

2 Departamento de Engenharia Rural, Universidade Estadual Paulista. Rua José Barbosa de Barros, 1.780, CEP 18610-307, Botucatu, SP, Brasil. E-mail: farool2@gmail.com.

3 Sistema de Informações da Bacia Hidrográfica do Ribeira de Iguape e Litoral Sul. Rua Felix Aby-Azar, 442, Centro, CEP 11900 000, Registro, SP, Brasil. E-mail: isisgeologia@gmail.com, alex@sigrb.com.br.

4 Instituto de Geociências, Universidade de São Paulo. Centro de Ciências Exatas e Tecnologia, Universidade Federal de Mato Grosso do Sul. Cidade Universitária, CEP 79070-900, Campo Grande, MS, Brasil. E-mail: antonio.paranhos@pq.cnpq.br.

Recebido em 06/2014. Aceito para publicação em 06/2015.

Versão online publicada em 19/08/2015 (www.pesquisasemgeociencias.ufrgs.br)

\begin{abstract}
The study area is a Water Resources Management Unit \#11 (WRMU-11), with steep slopes and very dissected and undulated relief, located in last continuous remaining parts of the Atlantic Forest in the State of São Paulo (Brazil). This paper presents a new predictive model for the identification of susceptible areas to erosion and landslides in the WRMU-11 region by combining geotechnical tools and field work. In order to evaluate the methodology, multi-criteria analysis was performed using the IDRISI Andes software. The areas that are more susceptible to erosion are located in Apiaí, Barra do Chapéu, Barra do Turvo, Cajati, Eldorado, Itaóca, Itapirapuã Paulista and Ribeira. 128 landslide occurrences observed in field surveys in the Ribeira de Iguape River Valley were plotted on the landslide susceptibility map. Ten occurrences were situated in areas classified as low susceptibility to landslides; fifty-six occurrences in areas of moderate susceptibility, fifty-five in areas of high susceptibility, and seven in areas were situated in areas of very high susceptibility to landslides. Field data showed that the Erosion and Landslide Susceptibility Maps, in 1:250,000 scale, provide reliable predictions.
\end{abstract}

Key-words: RUSLE, Susceptibility, landslide, GIS, WRMU-11.

Resumo -DesenVolvimento E AVALIAÇÃo DE UM MODELO PREDITIVO A PROCESSOS EROSIVOS E MOVIMENTO DE MASSA PARA A REgião COSTEIRA Do EsTAdo DE SÃo PAULO, BRASIL. A área de estudo é a Unidade de Gerenciamento de Recursos Hídricos número 11 (UGRHI-11), com declives acentuados, muito dissecados e relevo ondulado, localizada na última parte de remanescente contínuo da Mata Atlântica no Estado de São Paulo (Brasil). Este artigo apresenta um novo modelo de previsão para a identificação de áreas suscetíveis à erosão e deslizamentos de terra na região da UGRHI-11, combinando ferramentas geotécnicas e trabalho de campo. A fim de avaliar a metodologia, foi realizada uma análise multicritério utilizando o software IDRISI Andes. As áreas que são mais suscetíveis à erosão estão localizadas em Apiaí, Barra do Chapéu, Barra do Turvo, Cajati, Eldorado, Itaóca, Itapirapuã Paulista e Ribeira. 128 ocorrências de deslizamentos observados em pesquisas de campo em Ribeira de Iguape Vale do Rio foram plotados no mapa de suscetibilidade deslizamento de terra. Dez ocorrências estavam situadas em áreas classificadas como baixa suscetibilidade a deslizamentos de terra; cinquenta e seis ocorrências em áreas de susceptibilidade moderada, cinquenta e cinco em áreas de elevada susceptibilidade e sete áreas estavam situadas em áreas de elevada susceptibilidade a deslizamentos de terra. Os dados de campo mostraram que os mapas de suscetibilidade a erosão e deslizamento de terra, em escala 1:250.000, forneceram previsões confiáveis. Palavras-chave: RUSLE, suscetibilidade, deslizamentos, SIG, UGRHI-11. 


\section{Introduction}

Water Resources Management Unit \#11 (WRMU-11), is inserted in the hydrographic basin of the Ribeira de Iguape River and the southern coast of State of São Paulo - southern Brazil. It has great diversity of terrestrial and water environments, with extensive mountainous areas, steep slopes and floodplains, which contrast with coastal plains, mangroves, marine and river terrace landforms, and especially with the Iguape-Cananéia estuarine lagoon complex. WRMU-11 has great environmental importance because it contains the last continuous remnants of the Atlantic Forest, represented by Dense Ombrophilous Forest, Mixed Ombrophilous Forest, Semi-deciduous Seasonal Forest and associated ecosystems of sandbank and mangroves, as well as island ecosystems and karst environments. In addition, there are 16 state parks, one state forest, one wildlife reserve, and seven ecological stations over an area of 8,391.7 $\mathrm{km}^{2}$, which comprises the largest number of Conservation Units under Full Protection of the State of São Paulo. With 19 units of sustainable land use, including nine Sustainable Development Reserves (SDR), seven Environmental Protection Areas (EPA), and three Areas of Ecological Importance (AEI) spread over an area of $4,865.2 \mathrm{~km}^{2}$, the total area under protection sums $13.256 \mathrm{~km}^{2}$ (CBH-RB, 2010).

The environmental fragility of the area is high, not only regarding biodiversity, but also to geodynamic geomorphological processes, particularly high susceptibility to all types of erosion and soil and rock movements, such as landslides. Erosion and landslides occur in different regions of the world, but they are more likely to occur in areas of deep tropical weathering profiles and very intense rainfall, especially in coastal areas of underdeveloped or developing countries. Erosion and landslides have been extensively studied and experts have recommended corrective and preventive measures. Nevertheless, large-scale disasters related to weather conditions and mass movements still occur. Recent examples of great impact in Brazil include landslides in the Itajaí Valley (State of Santa Catarina) in November 2008 (UFSC, 2011); Angra dos Reis (State of Rio de Janeiro) in January 2010 (Barbosa et al, 2011); and in the mountainous region of Rio de Janeiro in January 2011 (DRM-RJ, 2011), resulting in a great number of casualties in all cases.

With preventive and/or corrective measures, it is possible to avoid deaths and mitigate damage to property. The use of geotechnical mapping aids assessment and representation of features of the physical and biological components of the environment, as well as the various forms of land use, and the natural and induced processes (Zuquette \& Gandolfi, 2004). Erosion and landslide susceptibility maps are geotechnical mapping products that can be used as guides to urban and rural planning, indicating areas of potential geological risk and thus assisting relocation of people building and living in these areas.

By combining geotechnical tools and field work, this study aims to develop and assess a new predictive model for the identification of susceptible areas to erosion and landslides in the WRMU11 region, in coastal region of the State of São Paulo, combining geotechnical tools and field work.

\section{Area, materials and methods}

\subsection{The study area}

Water Resources Management Unit \#11 (WRMU-11) corresponds to the hydrographic basin of the Ribeira do Iguape River located in the southern coast of the State of São Paulo (Fig. 1). It covers an area of 17,068 $\mathrm{km}^{2}$ (CBH-RB, 2010) and extends for $140 \mathrm{~km}$ along the Atlantic coast. The area is composed of twenty-three municipalities, with a total population of 361,224 people (IBGE, 2010). The main rivers in WRMU-11 are the Juquiá, Ribeira, Ribeira de Iguape, São Lourenço, Jacupiranga, Pardo, Una da Aldeia and Itariri. The reservoirs of Alecrim, Barra, França, Porto Raso, Salto de Iporanga and Serraria are located in the Ribeira de Iguape River basin, which is characterized by a very dissected and undulated relief, reaching altitudes higher than $1,000 \mathrm{~m}$, and by steep slopes. It predominantly belongs to the Coastal Province, which is bordered by the Atlantic Plateau, Serra do Mar and Paranapiacaba mountain ranges (Almeida, 1964; Ponçano et al., 1981).

\subsection{Methods}

The methodology used in this study involves the technical and operational approaches for geotechnical zoning and susceptibility analysis (Becker \& Egler, 1996; Ross, 2006a; Theodorovicz \& Theodorovicz, 2007; Miranda et al., 2008). Ross (2006b) describes the multi-level thematic analysis as a basic operational procedure used in the spatial distribution of geo-environmental information, which is characterized by the generation of analytical tools in the first stage, and later, by syn- 


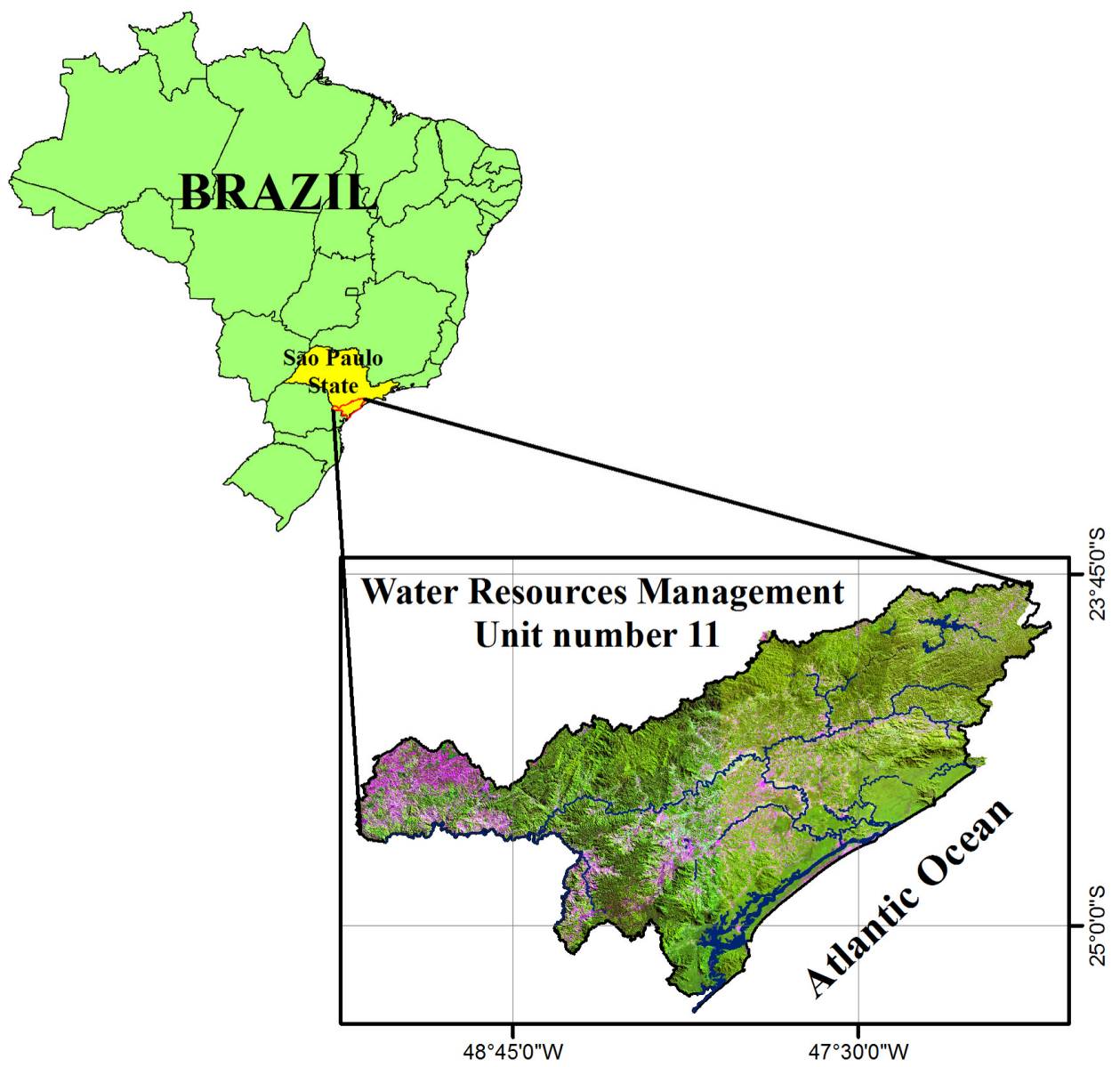

Fig. 1. Water Resources Management Unit \#11 (WRMU-11).

thesis. Thus, maps of susceptibility to erosion and to land sliding for WRMU-11 were derived from an integrated analysis of the elements of the physical environment. Field control was carried out in areas where these processes were prevalent. The cartographic base was obtained from the official charts at 1:50,000 scale. All field data and ground control points were checked by means of a Differential Global Positioning System receiver (DGPS), respecting the accuracy limits required for class $A$ cartographic charts (Federal Law 89.817, BRASIL, 1984). The Digital Elevation Model derived from these data is also in accordance with such accuracy limits. Thematic mapping was based on secondary and field data at 1:200,000 scale.

\subsubsection{Erosion susceptibility mapping}

The use of erosion models has been recommended in order to predict landform stability (Evans \& Loch, 1996). Soil erosion models are the mathematical descriptors used to represent the erosion process. They have been applied in the design of impoundments, erosion control structures, in the evaluation of land-use management practices and environmental planning and assessment. Wischmeier \& Smith (1965) developed the
Universal Soil Loss Equation (USLE), which is the most widely used of all soil erosion models. USLE estimates the average annual soil loss, using data related to rainfall, soil, topographic and land management characteristics. By modifying the topographic and cover-management factors in USLE and applying a more deterministic approach to calculate the support practice factor, Yoder et al. (1992) developed the Revised Universal Soil Loss Equation (RUSLE). In 1985, USDA initiated the Water Erosion Prediction Project or WEPP (Nearing et al., 1989), which is capable of predicting spatial and temporal distributions of net soil loss, or net soil loss or gain for the entire hillslope for any period of time. It also has a wider range of applicability as it contains its own process-based hydrology, water balance, plant growth, residue disposal, and soil consolidation models, as well as a climate generator and many other components that broaden its range of applicability (Tiwari et al., 2000).

Cecílio et al. (2009) worked in Viçosa watershed (Minas Gerais State, Brazil) and compared soil loss models obtained by RUSLE and WEPP, showing that the annual soil loss predicted by RUSLE is very similar to the value measured in the field. In some studies realized in USA evaluations of USLE, RUSLE and WEPP showed that USLE and 
RUSLE had better results than WEPP model on estimates of loss soil (Risse et al., 1993; Tiwari et al., 2000).

Our choice of methodology was based on the availability of data. The study area is extensive and it is very difficult to acquire enough data to be applied in WEEP. The creation of a database to be applied in RUSLE is comparatively simpler. Besides, RUSLE is a more appropriate model for WRMU-11 because, according to Ubierna et al. (2009), WEPP and USLE are not adequate for slopes characterized by high erosion rates. Thus, the erosion vulnerability map was developed using the Revised Universal Soil Loss Equation (Eq. 1) with the aid of the IDRISI Andes software, version 15.01 (Eastman, 2006). This empirical methodology developed by Wischmeier \& Smith $(1958,1978)$ expresses the combined action of natural (rainfall-runoff erosivity, soil erodibility, and landform characteristics) and anthropogenic factors (land use, management and conservation practices), which influence sheet erosion caused by raindrop splash. RUSLE is represented as follows:

\section{Eq. 1 A = R.K.L.S.C.P}

Where $\mathbf{A}=$ soil loss per unit area; $\mathbf{R}=$ rainfall erosivity: ability of rainfall to cause soil erosion in unprotected areas. It is related to kinetic energy, rainfall intensity and total sheet flow; $\mathbf{K}=$ soil erodibility: expresses soil resistance to erosion by water as a function of mineralogical, chemical, morphological and physical properties of the soil; $\mathbf{L}=$ slope length: ratio of soil loss from a given slope length to soil loss from a ramp length of 25 meters for the same soil and slope steepness; $\mathbf{S}=$ slope steepness: ratio of soil loss (erosion) from a given slope to soil loss from a $9 \%$ slope for the same soil and ramp length; $\mathbf{C}=$ soil use and management: ratio of soil loss in a cultivated land under certain conditions to the corresponding soil loss from land under the same conditions for assessment of the $\mathrm{K}$ factor; and, $\mathbf{P}=$ conservation practices: ratio of soil loss from a land cultivated according to a given system to soil loss with straight-row farming up and down the slope.

All parameters were standardized according to the International System (Foster et al., 1981). This procedure was developed by inserting erosivity and erodibility data in the Tab. of attributes of the vector file (shapefile) of the pedological map. Rasterization followed, so as to generate the erosivity and erodibility maps by means of ArcMap (ESRI, 2009), as proposed by Bertoni \& Lombardi (1990).
The pedological map was elaborated after Lepsch et al. (1999), who used a legend set up in 1960 for soil mapping (Oliveira, 1999). This does not create major difficulties to the purposes of the present study, since what matters for the calculations is the soil texture and structure rather than names. When applicable, updates of the current Brazilian System of Soil Classification (SBCS) are cited. A semi-automatic erosivity map was prepared at 1:250,000 scale.

\section{Rainfall erosivity factor}

The erosivity values were calculated based on the equation proposed by Bertoni \& Lombardi (1990), who obtained a reliable coefficient of correlation:

\section{Eq. $2 \mathrm{EI}=6.886 \times\left(\mathrm{p}^{2} / \mathrm{P}\right)^{0.85}$}

Where EI = average monthly rate of erosion in $\mathrm{MJ} / \mathrm{ha}-\mathrm{mm} ; \mathbf{r}=$ average monthly rainfall in $\mathrm{mm}$; and, $\mathbf{P}=$ average annual rainfall in $\mathrm{mm}$.

The data used in this equation were obtained from the Tropical Rainfall Measuring Mission (TRMM), from January 2000 to July 2013 (151 records). These images were clipped with the watershed boundary and vectorized (24 points). Erosivity was calculated for each point, according to Bertoni \& Lombardi (1990). After the computation of the monthly erosivity, the annual erosivity was calculated for each point, and after that, the average between January 2000 and July 2012 was obtained.

\section{Soil erodibility factor}

The erodibility values shown in tab. 1 and attributed to each soil class were obtained from Bertoni \& Lombardi (1990). The erodibility map was then developed plotting the erodibility values on the pedological map of Lepsch et al. (1999).

\section{Slope length and steepness factors ( $L$ and $S$ )}

The slope map was generated from a 1:50,000 scale topographic map, using 20 m-interval contour lines. It was first developed to be used with rasterized databases to generate a Numerical Terrain Model by means of the ArcMap software (ESRI, 2009). It was then transformed into a slope map using the IDRISI Andes software (Eastman, 2006). Subsequently, the slope map was reclassified (Tab. 2), according to Bertoni \& Lombardi (1990). 
Table 1. Erodibility values assigned to soil classes.

\begin{tabular}{lclc}
\hline \multicolumn{1}{c}{ Soil class } & $\begin{array}{c}\text { Erodibility } \\
\text { (t.h/M) }\end{array}$ & \multicolumn{1}{c}{ Soil class } & $\begin{array}{c}\text { Erodibility } \\
\text { (t.h/M) }\end{array}$ \\
\hline Purple Brunizem & 0.03 & Mangrove soil & 0.0009 \\
Alic cambisoil & 0.035 & Alluvial dystrophic soil & 0.001 \\
Dystrophic cambisol & 0.035 & Gleyzed alic soil & 0.0011 \\
Eutrophic cambisol & 0.035 & Dystrophic gleysol & 0.0011 \\
Yellow alic latosol & 0.0133 & Sulfurithionic gleysol & 0.0011 \\
Dystrophic una variation latosol & 0.0133 & Alic litholic soil & 0.0008 \\
Alic red-yellow latosol & 0.0133 & Dystrophic litholic soil & 0.0008 \\
Podsol & 0.027 & Alic organic soil & 0.0011 \\
Eutrophic grayish brown podzolic & 0.018 & Organic alic buried soil & 0.0011 \\
Alic yellowish red podzolic & 0.04 & Sulfurithionic organic soil & 0.0011 \\
Distrophic yellowish red podzolic & 0.0396 & Structured distrophic terre brune & 0.0133 \\
\hline
\end{tabular}

Soil use and management factor $(C)$ and conservation practices factor $(P)$

The $\mathrm{C}$ and $\mathrm{P}$ factors are treated independently in the Universal Soil Loss Equation. However, in the present study they were correlated. According to Stein et al. (1987), these factors are so strongly related to each other that they cannot be analyzed individually for the calculation of soil loss by erosion. Thus, a correlation between the $\mathrm{C}$ and $\mathrm{P}$ factors was derived (Tab. 3), based on Paranhos Filho et al. (2003).

Table 2. Length and Slope (LS) values assigned to slope classes.

\begin{tabular}{cc|cc}
\hline Slope (\%) & Factor LS & Slope (\%) & Factor LS \\
\hline 1 & 0.18 & 12 & 3.36 \\
2 & 0.41 & 14 & 4.03 \\
4 & 0.92 & 16 & 4.72 \\
6 & 1.48 & 18 & 5.43 \\
8 & 2.08 & 20 & 6.14 \\
10 & 2.71 & & \\
\hline
\end{tabular}

Table 3. Cover and management factor (C) and Support practice factor $(\mathrm{P})$ constitute $\mathrm{CP}$ values assigned to land use.

\begin{tabular}{lc|lc}
\hline \multicolumn{1}{c|}{ Description } & $\begin{array}{c}\text { CP } \\
\text { Factor }\end{array}$ & Description & CP Factor \\
\hline Airports & 0 & Mangroves & 0 \\
Field anthropic & 0.1 & Forest & 0.00004 \\
Wet fields & 0 & $\begin{array}{l}\text { Riparian } \\
\text { Forest }\end{array}$ & 0.00004 \\
$\begin{array}{l}\text { Bodies of water } \\
\begin{array}{l}\text { Agriculture } \\
\text { crop year }\end{array}\end{array}$ & 0 & Mining & 0.1 \\
$\begin{array}{l}\text { Agriculture } \\
\text { perennial }\end{array}$ & 0.2 & Reforestation & 0.0001 \\
$\begin{array}{l}\text { Semi-perennial } \\
\text { crops }\end{array}$ & 0.01 & Restingas & 0 \\
Industrial & 0 & Urban area & 0 \\
\hline
\end{tabular}

\subsubsection{The Landslide Susceptibility Map}

Lithological, geomorphological, pedological, and vegetation cover elements that characterize the physical environment were used for analysis of landslide susceptibility. Multi-criteria analysis was performed using the IDRISI Andes software (Eastman, 2006), though some preliminary stages were developed with the ArcMap software (ESRI, 2009).

The Weighted Linear Combination (WLC) module of the IDRISI Andes software was used in the multi-criteria analysis that included correlations between slope, geological, pedological, vegetation and geomorphological maps.

\section{Slope map}

In this study the slope map was obtained using 20 m-interval contour lines of 1:50,000-scale maps produced by the Brazilian Institute of Geography and Statistics (IBGE), scanned by the Geographic and Cartographic Institute of the State of São Paulo (IGC) and incorporated to the GIS-RB. Firstly, a Digital Elevation Model (DEM) was generated using the ArcMap software (ESRI, 2009). Next, a slope map based on the DEM was developed with the IDRISI Andes software (Eastman, 2006).

\section{Geologic map}

The geologic map was obtained from the Information System for the Ribeira de Iguape River Hydrographic Basin and Southern Coast of the State of São Paulo (GIS-RB) at 1:250,000 scale (Campanha, 2007).

\section{Pedological map}

Slope stability is a function of the intensity of 
rainfall, infiltration rates, and pressures in soil. The chemical and mineralogical characteristics of the soil are fundamental for a slip to occur, since they influence the properties of the clay. A geo-referred vector map and a database were developed based on the "Levantamento de reconhecimento com detalhes dos solos da região do Ribeira de Iguape no Estado de São Paulo" mapping at 1:250,000 scale (Lepsch et al., 1999).

\section{Soil coverage, geomorphology and rainfall erosivity}

The data of the soil coverage were obtained from the Information System for the Ribeira de Iguape River Hydrographic Basin and Southern Coast of the State of São Paulo (GIS-RB) at 1:250,000 scale.

Geomorphological data were obtained from the Information System for the Ribeira de Iguape River Hydrographic Basin and Southern Coast of the State of São Paulo (GIS-RB) at 1:250,000 scale and were originally based on Ross (2002).

The erosivity values were calculated based on the equation proposed by Bertoni \& Lombardi (1990), who obtained a reliable coefficient already described in this article in "2.2.1 Rainfall erosivity factor".

\subsubsection{Standardization of criteria}

Standardization of criteria was necessary because of the quantitative and qualitative dif- ferences between the criteria used in this assessment. The fuzzy module in IDRISI Andes makes standardization of criteria possible by providing the options of standardization both for a binary scale (zero and one) and for a scale with byte values, ranging from 0 to 255 ( 8 bits). This last option is recommended because the IDRISI Andes MCE module was designed for faster processing with bytes (Eastman, 2006).

\subsubsection{Weighting of criteria}

Many factors were used in multi-criteria analysis for the derivation of landslide vulnerability maps, and it is essential to determine the weights of the classes that make up these factors. These factors are lithology, soil coverage, pedology, geomorphology and rainfall erosivity. The weights of the equation parameters were obtained from several maps produced with different weights and field control data were used to validate the best results.

\section{Lithology, soil coverage and pedology}

Based on Crepani et al. (2010), who weighted lithology classes from 0 to 3 (least to most landslide susceptible), WRMU-11 lithological classes were given the weights (Tab. 4). Also from Crepani et al. (2001), WRMU-11 soil classes were given the weights (Tab. 5), as well as pedological classes were given the weights (Tab. 6).

Table 4. Lithological classes and their weights.

\begin{tabular}{lc|lc}
\hline \multicolumn{1}{c}{ Lithological classes } & Weights & \multicolumn{1}{c}{ Lithological classes } & Weights \\
\hline Alkaline indiscriminate & 0.6 & Meta-Basic, amphibolites & 1.8 \\
Alluvium & 3 & Meta-varvites, slates and phyllites & 2.1 \\
Carbonatites & 0.6 & Metabrechas & 2.1 \\
Carbonate phyllites & 2.1 & Metassiltites & 2.1 \\
Carbonate-schist & 2.1 & Mica & 2.4 \\
Phyllites & 2.1 & Migmatites & 1.3 \\
Fine schists and phyllites & 2.4 & Migmatites stromatolitic & 1.8 \\
Gabbros and Diabasios & 1.6 & Mylonites and cataclasite & 1.7 \\
Quartz diorite and granite gneisses & 1.1 & Marbles & 2.3 \\
Granite quartz syenite & 1.1 & Dolomite marble and mica & 0.6 \\
Gneiss granulites & 1.2 & Nepheline syenite & 1.4 \\
Hornfels & 1.2 & Orthogneisses & 1.2 \\
Ijolitos & 0.6 & Peridotites & 0.6 \\
Jacupiranguitos & 0.6 & QF & 2.4 \\
Mud & 0.6 & Quartzitic & 1 \\
Meta-sandstone & 2.1 & Migmatized Schists & 2.4 \\
\hline
\end{tabular}


Table 5. Soil classes and their weights.

\begin{tabular}{|c|c|}
\hline Land use classes & Weights \\
\hline Agriculture crop cycle & 2.9 \\
\hline Agriculture permanent crops & 3.0 \\
\hline Sand & 0.5 \\
\hline Field anthropic & 2.7 \\
\hline Tropical rain forest / Araucaria forest & 1.2 \\
\hline Body of water & 0.0 \\
\hline High montane tropical rainforest & 1.0 \\
\hline Tropical rainforest of the lowlands & 1.0 \\
\hline Montane tropical rainforest & 1.0 \\
\hline Lowland tropical rainforest & 1.0 \\
\hline Mixed montane rainforest & 1.3 \\
\hline Training tree / shrub-herbaceous land muddy marine & 1.4 \\
\hline Training tree / shrub-herbaceous floodplain & 1.4 \\
\hline Training pioneer shrub-herbaceous on recent marine sediments & 2.3 \\
\hline Mining & 3.0 \\
\hline Pisciculture & 0.0 \\
\hline Reforestation of Eucalyptus & 1.5 \\
\hline Pine reforestation & 1.5 \\
\hline Exposed soil & 3.0 \\
\hline Uurban area & 3.0 \\
\hline Secondary vegetation of tropical rainforest of the lowlands & 1.5 \\
\hline Secondary vegetation of montane tropical rainforest & 1.5 \\
\hline Secondary vegetation of lowland tropical rain forest & 1.5 \\
\hline Secondary vegetation of high montane tropical rainforest & 1.5 \\
\hline Secondary vegetation of mixed high-montane rainforest & 1.8 \\
\hline Secondary vegetation of mixed montane rainforest & 1.8 \\
\hline Secondary vegetation formation / shrub-herbaceous floodplain & 1.9 \\
\hline Secondary vegetation formation / shrub-herbaceous land muddy marine & 1.9 \\
\hline Secondary vegetation pioneer formation shrub-herbaceous on recent marine sediments & 2.8 \\
\hline Secondary vegetation tropical rain forest / Araucaria forest & 1.7 \\
\hline
\end{tabular}

Table 6. Pedologic classes and their weights.

\begin{tabular}{lc|lc}
\hline \multicolumn{1}{c}{ Pedologic classes } & Weights & \multicolumn{1}{c}{ Pedologic classes } & Weights \\
\hline Purple Brunizem & 2 & Mangrove soil & 3 \\
Alic cambisoil & 2.5 & Alluvial dystrophic soil & 3 \\
Dystrophic cambisol & 2.5 & Gleizado alic soil & 3 \\
Eutrophic cambisol & 2.5 & Dystrophic gleysol & 3 \\
Yellow alic latosol & 1 & Sulfurithionic gleysol & 3 \\
Dystrophic una variation latosol & 1 & Alic litholic soil & 3 \\
Alic red-yellow latosol & 1 & Dystrophic litholic soil & 3 \\
Podsol & 2 & Alic organic soil & 3 \\
Eutrophic grayish brown podzolic & 2 & Organic alic buried soil & 3 \\
Alic yellowish red podzolic & 2 & Sulfurithionic organic soil & 3 \\
Distrophic yellowish red podzolic & 2 & Structured distrophic terre brune & 2 \\
\hline
\end{tabular}

\section{Geomorphology}

According to these facts, geomorphological classes were weighted according to slope steepness and density of drainage lines. Thus, the steep- er the slope and the denser the drainage, the higher the vulnerability to landsliding. The WRMU-11 gemorphological classes were given the weights (Tab. 7). 
In the present study, the weighting process began with the establishment of a hierarchy of criteria, and previous standardization in the fuzzy logic in the 0-255 range, from the least to the most influential factor. Using the weight module of the IDRISI Andes software (Eastman, 2006) the criteria were placed on a matrix to perform all possible pairwise comparisons, and, thus, all factors were compared with each other, which resulted in the determination of all the weights (Tab. 8).
Table 7. Geomorphology and their weights.

\begin{tabular}{lc}
\hline \multicolumn{1}{c}{ Geomorphologic classes } & Weights \\
\hline Plateau and Paranapiacaba mountain & 4 \\
Baixo Ribeira tectonic depression & 1 \\
Guapiara plateau & 2 \\
Alto Ribeira do Turvo plateau & 2 \\
Iguape-Cananeia coastal plain & 1 \\
Baixo Ribeira river terraces and plateau & 1 \\
Serra do mar mountain and coastal hills & 4 \\
\hline
\end{tabular}

Table 8. Paired comparison of the factors involved.

\begin{tabular}{lccccc}
\hline & Pedology & Geology & Geomorphology & Vegetation & Slope \\
\hline Pedology & 1 & & & & \\
Geology & 3 & 1 & & & \\
Geomorphology & 3 & 1 & 1 & & \\
Vegetation & 5 & 1.75 & 1.75 & 1 & \\
Slope & 5 & 1.75 & 1.75 & 1 & 1 \\
\hline
\end{tabular}

\section{Rainfall erosivity}

The weighting process was not applied to rainfall erosivity. This factor was standardized only. The values range between 757.28 and 912.05 $\mathrm{MJ} / \mathrm{ha}-\mathrm{mm}$. Thus, this interval was transformed to an interval from zero to 255 . The average consistency of the weights is zero, which according to the IDRISI Andes software (Eastman, 2006), is an acceptable value.

The used Weights are Pedology: 0.0714; Geology: 0.1429; Geomorphology: 0.1429; Slope: 0.2143; Rainfall erosivity: 0.2143; Soil coverage: 0.2143 .

\subsubsection{Validation of the maps}

In order to check the accuracy of the landslide and erosion vulnerability maps, data obtained during the field work for the project Levantamento e Monitoramento de Áreas de Risco na WRMU-11 e apoio à Defesa Civil (Survey and Monitoring of Risk Areas in WRMU-11 and support to the Civil Defense Department) were used. Part of the methodology of this project included a field survey to quantify susceptibility to hazards such as landslides, erosion and flood in the twenty-three cities located in WRMU-11. The validation data were gathered on the information on the landslide and erosion vulnerability risk areas in the field work, which included visits to obtain geographic coordinates (using Differential Global Positioning System receptors), the elaboration of reports and photographic records.

The 'Extraction by Mask' tool of the Arc-
Map software (ESRI, 2009) was used to clip the landslide susceptibility map with the vector file (shapefile) for landslide-prone areas, as indicated by municipal representatives. Thus, it was possible to obtain the percentage of pixels classified as 'Very Low', 'Low', 'Moderate', 'High', and 'Very High' susceptibility to landsliding and to compare this result with the data acquired in the field.

\section{Results}

Besides the generation of landslide and erosion susceptibility maps, the model obtained for WRMU-11 may be upgraded and the main advantage of this system is provided of easily entering a new soil/vegetation map in order to periodically update the database. Other thematic maps such as type of human occupation in critical areas and risk calculation could be used, which demonstrate the versatility of the model obtained.

This GIS contains not only landslide and erosion susceptibility maps, but also other digital thematic maps used in the process, satellite images and field data. All files described here are downloadable at the site of the Information System for the Ribeira de Iguape River Hydrographic Basin and Southern Coast of the State of São Paulo (www.sigrb.com.br).

The Erosion Susceptibility Map indicated that the areas of greater susceptibility to erosion are located in the cities of Apiaí, Barra do Chapéu, Barra do Turvo, Cajati, Eldorado, Itaóca, Itapirapuã Paulista and Ribeira. The that most of the study area is located in areas susceptible to erosion, affecting zero to 56 tonnes per hectare per year (Fig. 2). 


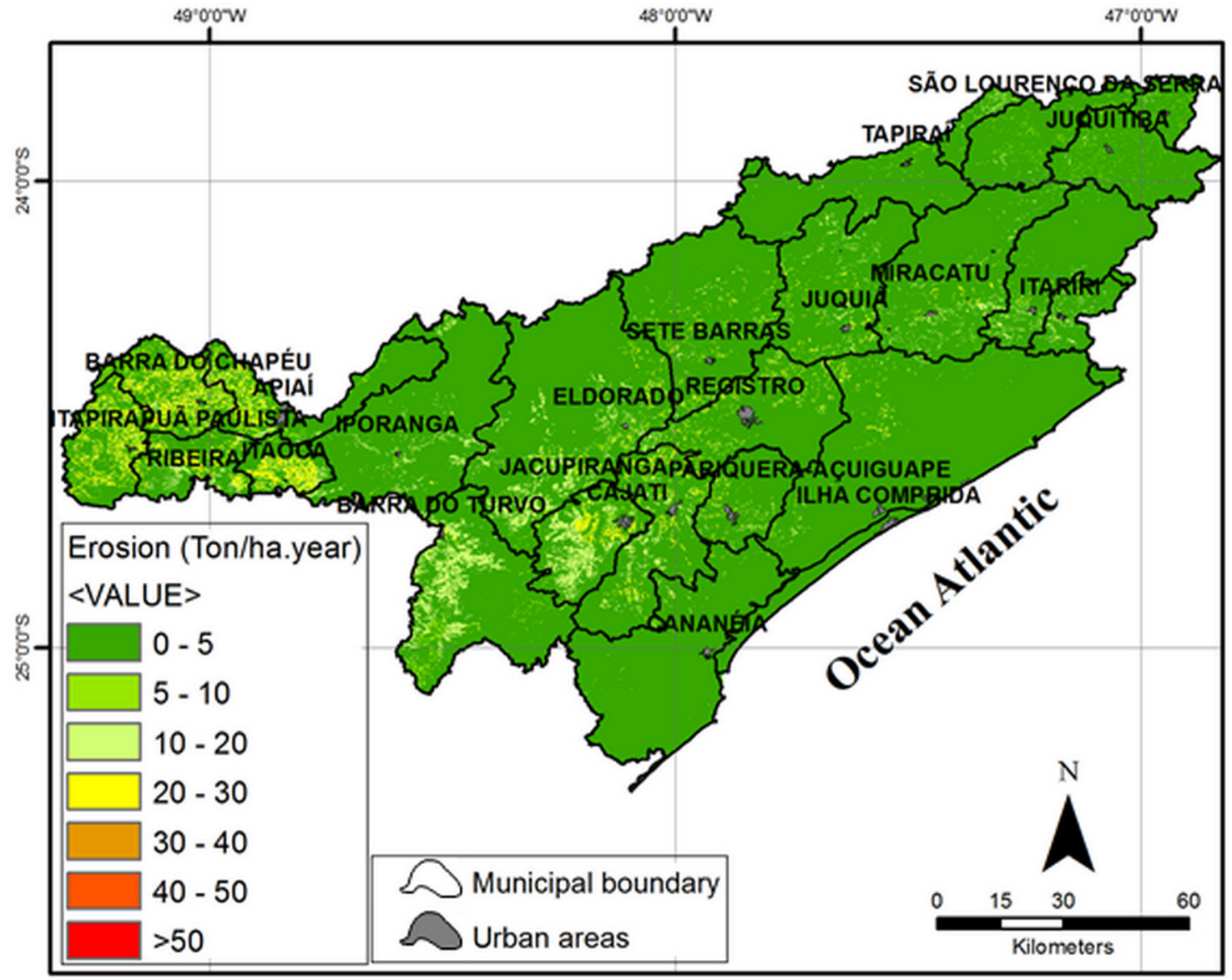

Fig. 2. Erosion Susceptibility Map.

The Landslide Susceptibility Map shows that only $2.36 \%$ of WRMU- 11 total area is classified as of very low susceptibility to landsliding; $21.97 \%$ as of low susceptibility; $47.08 \%$ as of moderate susceptibility; $26.47 \%$ as of high susceptibility, and $2.12 \%$ as of very high susceptibility (Tab. 9). The high to very high susceptibility to landsliding class occupies $28.6 \%(4,879.71 \mathrm{~km} 2)$ of WRMU-11 total area $(17.067 .92 \mathrm{~km} 2)$, where a that high rainfall may trigger risk situations (Fig. 3).

Table 9. Landslides susceptibility map areas.

\begin{tabular}{lcc}
\hline \multicolumn{1}{c}{ CLASS } & Area (sk) & Area (\%) \\
\hline Very low & 394.41 & 2.36 \\
Low & 3673.66 & 21.97 \\
Moderate & 7872.53 & 47.08 \\
High & 4427.35 & 26.47 \\
Very low & 355.24 & 2.12 \\
\hline
\end{tabular}

Only ten out of 128 inspected areas (7.81\%) were classified as of low susceptibility to landsliding; $56(43.75 \%)$ as of moderate susceptibility; $55(42.97 \%)$ as of high susceptibility; and seven $(5.47 \%)$ as of very high susceptibility to landsliding (Tab. 10). Therefore, out of 128 inspected areas, 62 landslides (48.44\%) occurred in areas of high to very high landslide susceptibility, according to the Landslide Susceptibility Map.

Table 10. Landslides Susceptibility of Inspected Areas.

\begin{tabular}{ccc}
\hline Classes of susceptibility & Total & $(\%)$ \\
\hline Low & 10 & 7.81 \\
Moderate & 56 & 43.75 \\
High & 55 & 42.97 \\
Very low & 7 & 5.47 \\
\hline
\end{tabular}

Seven areas in Barra do Turvo city with landslide problems were inspected. In BAR-5-3 (longitude: $48^{\circ} 27^{\prime} 54.46^{\prime \prime} 0$, latitude: $24^{\circ} 55^{\prime} 28.90^{\prime \prime} \mathrm{S}$ ), show in Fig. 4a, vegetation is present but it is still growing. It is possible that the steep slopes triggered landslide processes. The area is classified as of high susceptibility in the Landslide Susceptibility Map (Fig. 4b and Fig. 4c).

In Cajati (sixteen areas inspected), the weathered rock profile is very thick at CAJ-6-1 (longitude: $48^{\circ} 6^{\prime} 32.81^{\prime \prime} 0$, latitude: $24^{\circ} 43^{\prime} 55.26^{\prime \prime} \mathrm{S}$ ), show in Fig. 5a. In association with heavy rainfall and scarce vegetation, landslides are expected to occur. A landslide occurred in an area of high susceptibility (Fig. 5b and Fig. 5c). 


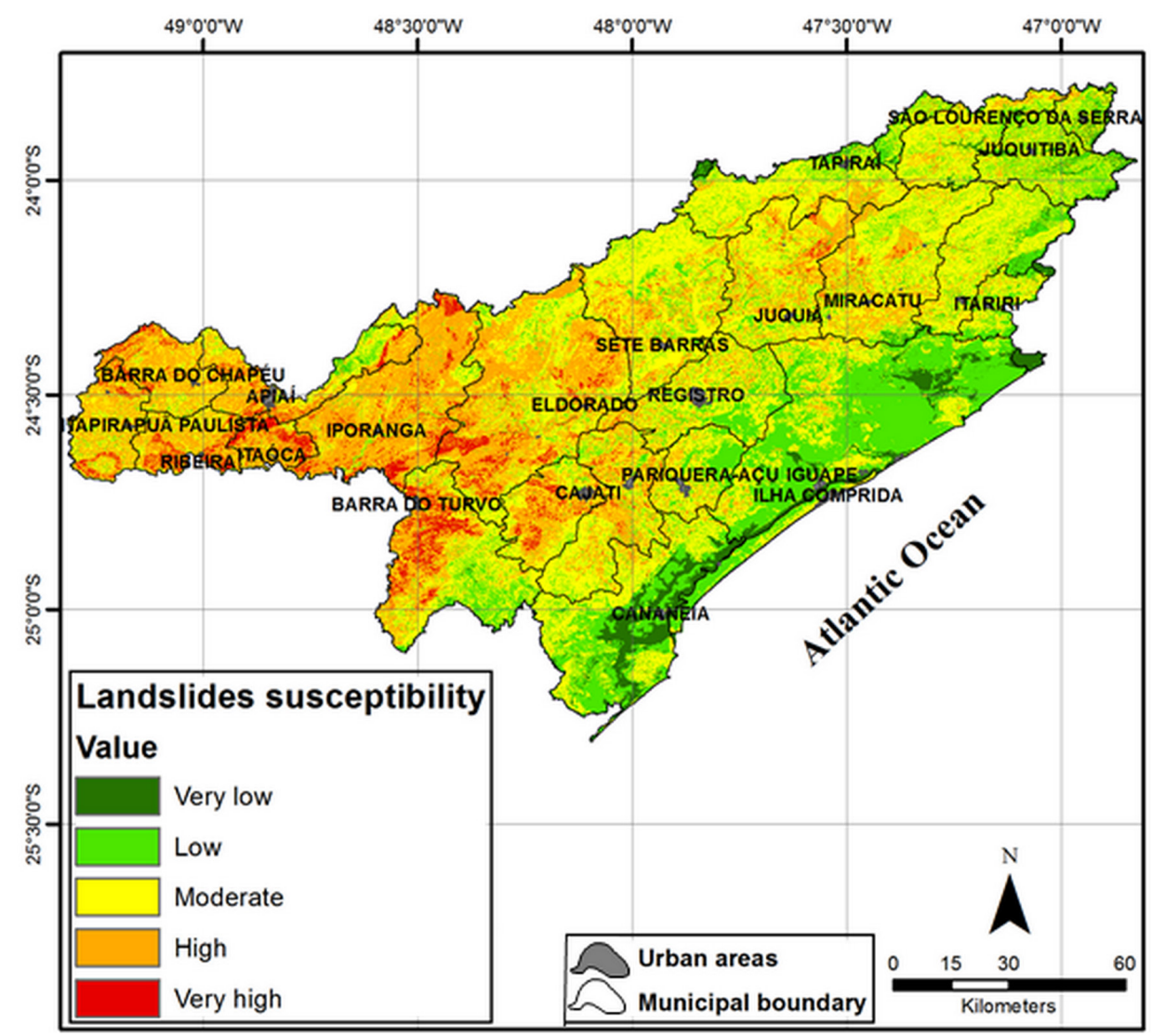

Fig. 3. Landslide Susceptibility Map.

In Eldorado, where landslides occurred in nine sites located in ELD-8-2 (longitude: $48^{\circ} 16^{\prime} 34.79^{\prime \prime} 0$, latitude: $24^{\circ} 35^{\prime} 50.89^{\prime \prime} \mathrm{S}$ ), show in Fig. 6a, the situation is similar to that shown in fig. $5 \mathrm{c}$ (scarce vegetation and steep slopes). It is located in an area of very high susceptibility (Fig. 6b and Fig. 6c).

\section{Discussion}

The Erosion Susceptibility Map was drawn according to the RUSLE. Given the favourable results of the field control, this technique seems to be suitable in terms of the proposed objective. Although the final map contains quantitative data, the model proposed here is better used as a qualitative indicator of risk areas.

Erosion is related to physical characteristics such as the amount and distribution of rainfall, slope steepness, length and shape of the slope, type of vegetation and also the action of man (Guerra \& Mendonça, 2004). A different process is landsliding, which is the movement of a large volume of material (soil and rock) down slope by the influence of gravity (main factor), being triggered by direct interference of independent media, such as water, ice or air (Bigarella, 2003). Thus, both events do not necessarily have to occur in the same location or at the same time.

The type of vegetation is an important factor in determining areas susceptible to landslides. Landslides can be induced in areas with steep slopes and large vegetation cover because a large volume of rain combined with the presence of shallow soil can cause overloading on the surface of bedrock. However, in certain areas the presence of vegetation can minimize landsliding (Nummer, 2003). Monguilhott (2008) confirms the beneficial effects of vegetation on slope stability, as the removal of vegetation increases the speed in which landsliding takes place.

The efficiency of the Landslide Susceptibility Map is demonstrated and quantified by field control. In $48.44 \%$ of the 128 inspected sites, landslides occurred in areas classified as of high to very high vulnerability. The remaining $51.56 \%$ were ranked as of 'low' and 'moderate' susceptibility. However, these situations do not diminish the importance and the accuracy of the map produced because some landslides were caused by anthropic action, with the creation of artificial slopes for the construction of simple dwellings. It is important to note that none of inspected sites were located in areas classified as of very low vulnerability. This fact corroborates with the accuracy of the landslide susceptibility map. 
The areas indicated as of high susceptibility to landsliding are those identified by the municipalities of Barra do Turvo and Cajati. In Eldorado, such areas were classified as of very high susceptibility. Field inspection demonstrated that landslides have occurred in these areas. As observed in the Landslide Susceptibility Map, the areas of greater landslide susceptibility are located in Barra do Turvo, Eldorado, Cajati and Barra do Chapéu, probably because of the very dissected and undulating relief (Figs. 5-7).

According to Crepani et al. (2001), relief dissection is associated with soil and rock porosity and permeability. Impermeable rocks and soils hinder the infiltration of rainwater and consequently surficial drainage is more intense. A larg- er volume of water being drained on the surface leads to greater availability of potential energy for runoff and a greater ability to promote morphogenesis. The less intense dissection is, the less vulnerable the slope is to landsliding (values close to stability). On the other hand, the more intense dissection is, the more vulnerable the relief is to landsliding.

Despite the regional scale, the present model was successful in the identification of the most critical areas in WRMU-11. Further detailed studies are needed to aid mitigation actions and to support the preventive plans of the municipal civil defense departments, urban and rural planning, and ecological and economic zoning.

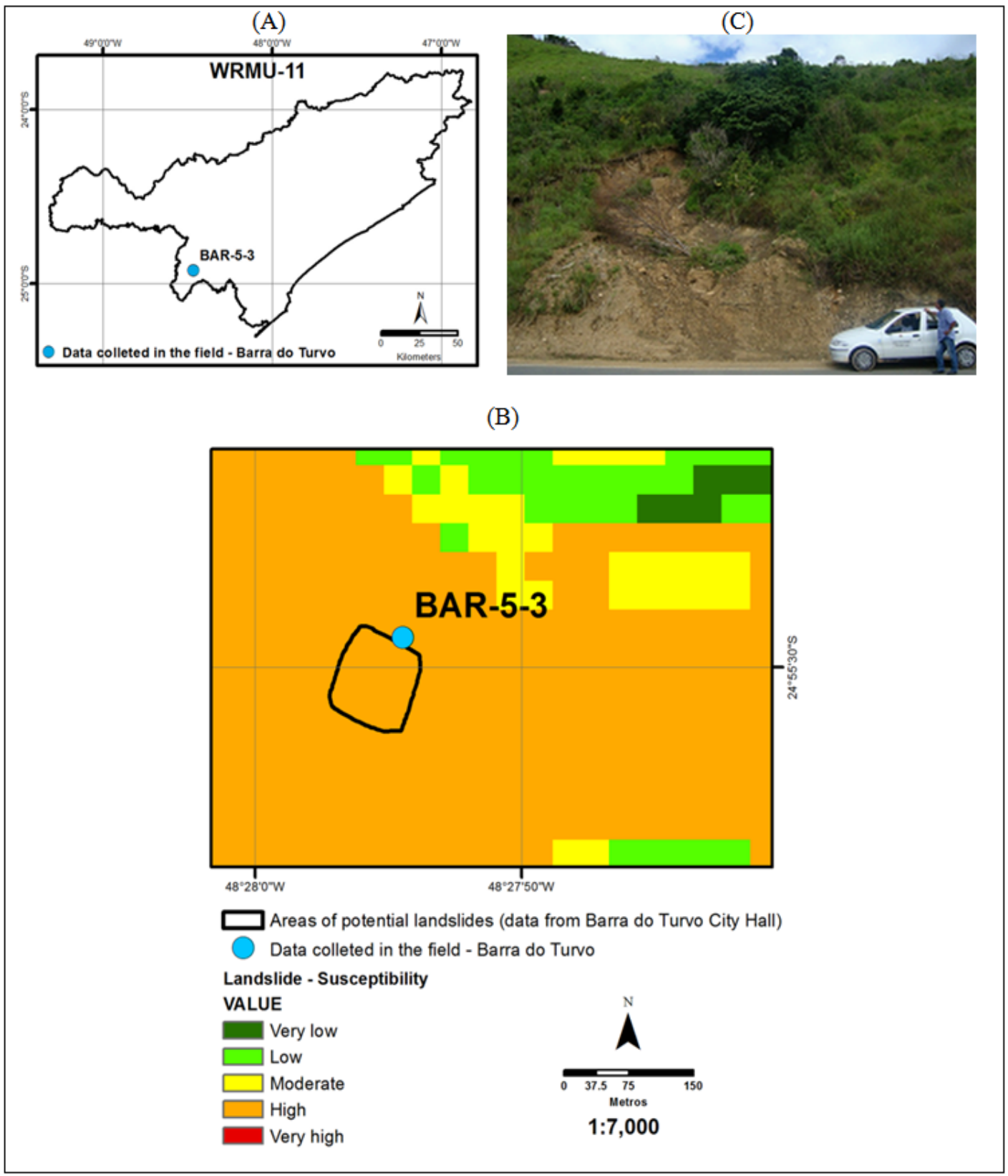

Fig. 4. Landslides in the Barra do Turvo city (Sector BAR-5-3): A) Sector localization; B) Landslides map; C) Landslide photograph register. 


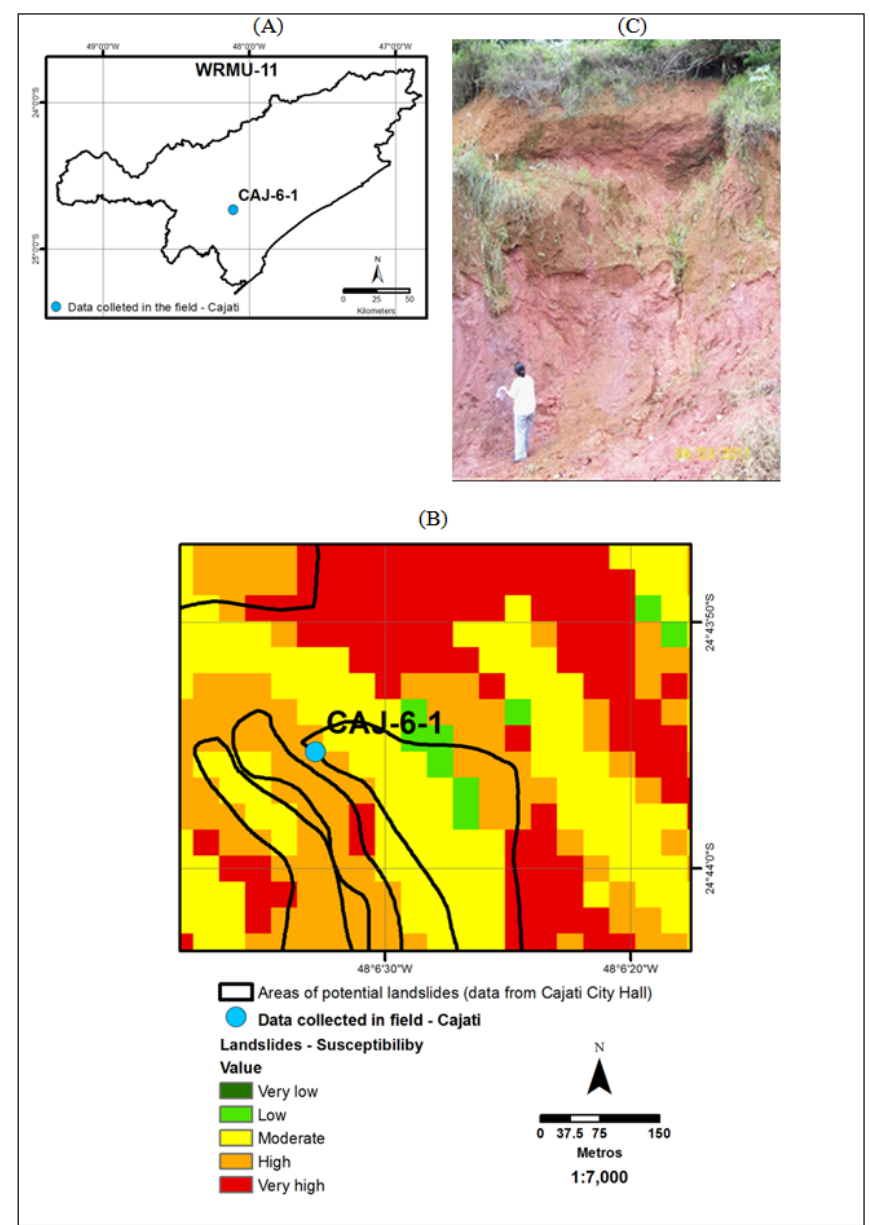

Fig. 5. Landslides in the Cajati city (Sector CAJ-6-1): A) Sector localization; B) Landslides map; C) Landslide photograph register.
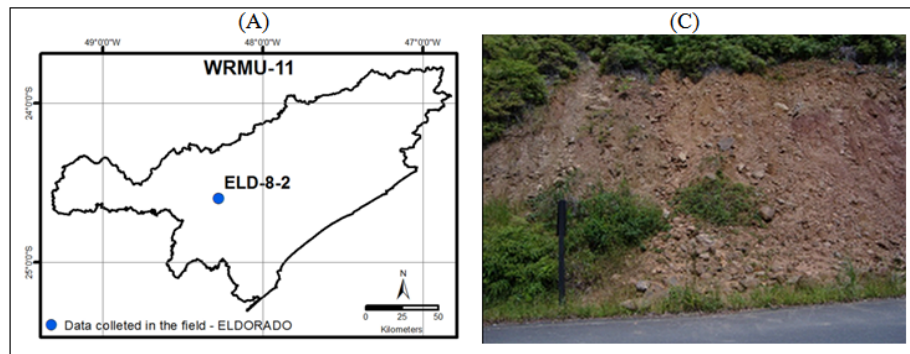

(B)

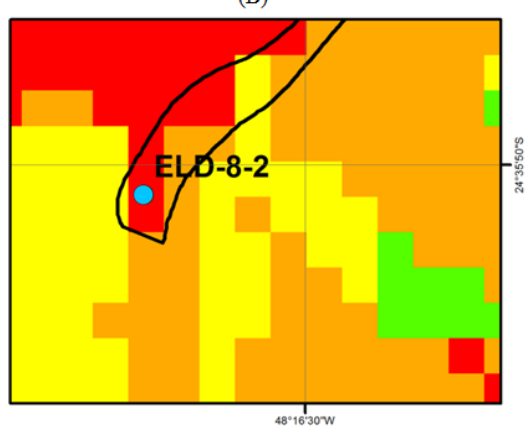

Areas of potential landslides (data from Eldorado City Hal)

Data collected in the field - Eldorado

Landslides - Susceptibility

Value

$\square$ Low low

$\square$ Modera

Very high

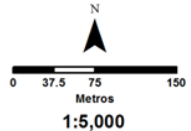

Fig. 6. Landslides in the Eldorado city (Sector ELD-8-2): A) Sector localization; B) Landslides map; C) Landslide photograph register. 


\section{Conclusions}

Erosion and landsliding can have natural or anthropogenic causes. Human activities should be carefully carried out to prevent instability and erosion. The problems due to these hazards have been exacerbated by the migration of people from rural areas to unoccupied areas in the cities, most of which are at geological or hydrological risk.

Ten occurrences were situated in areas classified as low susceptibility to landslides; fifty-six occurrences in areas of moderate susceptibility, fifty-five in areas of high susceptibility, and seven in areas were situated in areas of very high susceptibility to landslides. Field data showed that the Erosion and Landslide Susceptibility Maps have provide reliable predictions

The use of GIS allowed the integration of data from different sources that, combined, led to the development of regional wide erosion and landslide susceptibility mapping. Field data showed that the Erosion and Landslide Susceptibility Maps, in 1:250,000 scale, provide reliable predictions. A good correlation was obtained between field data and cartographic products. When compared to traditional techniques of geotechnical mapping the methodology applied in this study can be usefull to economy of time and resources in this kind of search.

Acknowledgments- This work was supported by the CAPES- Coordination Board for the Improvement of Higher Education Personnel, for granting the Ph.D scholarship (Programa de Demanda Social) to Fabrício Bau Dalmas, Graduate student in the Graduate Program in Geosciences at the Instituto de Geociências da Universidade de São Paulo, and Fundo Estadual de Recursos Hídricos do Estado de São Paulo for the financial support to the Project Levantamento $e$ monitoramento de áreas de risco na WRMU-11 e apoio à Defesa Civil run by the Committee for the Ribeira de Iguape River Hydrographic Basin and Southern Coast of the State of São Paulo, and CNPq - National Council for Scientific and Technological Development, for the Senior Postdoctoral Fellowship granted to Antonio C. Paranhos Filho (Process 151762/2010-4). Special acknowledgments to reviewers of Pesquisas em Geociências by the corrections and suggestions during the process of submition this article.

\section{References}

Almeida, F.F.M. 1964. Fundamentos geológicos do relevo paulista. Geologia do Estado de São Paulo. Boletim do Instituto Geográfico e Geológico, 41: 169-263

Barbosa, Z.N.T., Oliveira, W.N.O. \& Alves, P.R. 2011. Uso de geotecnologias para mapeamento de áreas de ris- cos. Estudo de caso: Angra dos Reis - RJ. In: BRAZILIAN SYMPOSIUM ON REMOTE SENSING, $15^{\text {th }}$, Curitiba, Brazil, Proceedings..., INPE, p. 4940.

Becker B.K. \& Egler C.A.G. 1996. Detalhamento da metodologia para execução do ZEE pelos Estados da Amazonia Legal. Rio de Janeiro, LAGET/UFRJ/SAE-PR, 40p.

Bertoni, J. \& Lombardi, N.F. 1990. Conservação do solo. Editora Ícone. São Paulo. 353p.

Bigarella, J.J. 2003. Estrutura e origem das paisagens tropicais e subtropicais Florioanópolis, Editora da UFSC, Florianópolis, v. 3, 1436p.

BRASIL. 1984. Decreto $n^{\circ} 89.817$ de 20 de junho de 1984. Normas Técnicas da Cartografia Nacional, Diário Oficial da União, Brasília, Brasil.

Campanha, G.A.C. 2007. Relatório de Situação dos Recursos Hídricos da UGRHI-11. Cap. 2.2.1 Geologia. In: CBH-RB. Comitê de Bacia Hidrográfica do Ribeira de Iguape e Litoral Sul. 2008. Available at: http://www. sigrb.com.br. Accessed on 1st June 2010.

CBH-RB. Comitê de Bacia Hidrográfica do Ribeira de Iguape e Litoral Sul. 2010. Relatório de Situação dos Recursos Hídricos da WRMU-11. Available at: http:// www.sigrb.com.br. Accessed on 3rd June 2010.

Cecílio, R.A., Rodriguez, R.G., Baena, L.G.N., Oliveira, F.G. \& Pruski, F.F. 2009. Aplicação dos modelos RUSLE e WEPP para a estimativa da erosão hídrica em microbacia hidrográfica de Viçosa (MG). Revista Verde de Agroecologia e Desenvolvimento Sustentável, 4(2): 39-45.

Crepani, E., Medeiros, J.S., Hernandez, F.P., Florenzano, T.G., Duarte, V. \& Barbosa, C.C.F. 2001. Sensoriamento Remoto e Geoprocessamento aplicados ao Zoneamento Ecológico-Econômico e ao Ordenamento Territorial. São José dos Campos, INPE. 103 p..

Crepani, E., Medeiros, J.S., Azevedo, L.G.D., Hernandez, F.P., Florenzano, T.G. \& Duarte, V. 2010. Curso de sensoriamento remoto aplicado ao zoneamento ecológico-econômico. São José dos Campos, INPE, 25 p.

DRM-RJ. Departamento de Recursos Minerais. Serviço Geológico do Estado do Rio de Janeiro. 2011. Megadesastre da Serra (jan. 2011). Available at: http://www.drm.rj.gov.br/index.php/component/ content/article/31-home/215-servico-geologico-do-estado- do-rio-de-janeiro-divulga-diagnostico-sobre-o-mega-desastre-na-serra-fluminense. Accessed on 18th December 2011.

Eastman, J.R. 2006. Guide to GIS and Imaging Processing. IDRISI Andes Manual: Version 15.0. Worcester, MA, Clark Labs of Clark University, 328 p.

Evans, K.G. \& Loch, R.J. 1996. Using the RUSLE to identify factors controlling erosion rates of mine soils. Land Degradation and Development, 7: 267-277.

ESRI. Environmental Systems Research Institute. 2009. ARCMap version 9.3.3. Environmental Systems Research Institute Inc., New York.

Foster, G.R., Mccool, D.K., Renard, K.G. \& Moldenhauer, W.C. 1981. Conversion of the universal soil loss equation to SI metric units. Journal of Soil and Water Conservation, 36(6): 355-359.

Guerra, A.J.T. \& Mendonça, J.K.S. 2004. Erosão dos Solos 
e a Questão Ambiental. In: Reflexões sobre a Geografia Física no Brasil. Guerra AJT \& Vitt CA (organizadores.). Ed. Bertrand Brasil, Rio de Janeiro, p. 225251.

IBGE. Instituto Brasileiro de Geografia e Estatística. 2010. Censo Demográfico 2010. Resultados divulgados no Diário Oficial da União em 04.11.2010. Available at: http://www.ibge.gov.br/home/estatistica/ populacao/censo2010/resultados_dou/default_resultadosdou.shtm. Accessed on 9th May 2011.

Lepsch, I.F., Prado, H., Menk, J.R.F., Sakai, E. \& Rizzo, L.T.B. 1999. Levantamento de reconhecimento com detalhes dos solos da região do Ribeira de Iguape no Estado de São Paulo. Governo do Estado de São Paulo, Secretaria de Agricultura e Abastecimento, IAC, Escala 1:250.000.

Miranda, E.E., Coutinho, A.C., Guimarães, M. \& Vaz, M. 2008. O zoneamento Ecológico Econômico do Estado do Maranhão. Available at: <http://www.cnpm. embrapa.br/publica/download/newsdownload/ artigos_resumos\%20anais\%20eventos/rpc_gisbrasil02_zeema_mir.pdf $>$. Accessed on 18th October 2008.

Monguilhott, M. 2008. Estudo de áreas suscetíveis a movimentos de massa na rodovia RS/486 - Rota do Sol. Porto Alegre, 115p. Monografia de Conclusão de Curso, Curso de Geografia, Instituto de Geociências, Universidade Federal do Rio Grande do Sul.

Nearing, M.A., Foster G.R., Lane L.J. \& Finkner, S.C. 1989. A process-based soil erosion model for USDA Water Erosion Prediction Project Technology. American Society of Agricultural Engineers, 32(5): 1587-1593.

Nummer, A.V. 2003. Parâmetros geológicos-geotécnicos controladores dos movimentos de massa na Rota do Sol/RS/486 - Itati, RS. Porto Alegre, 220p. Tese de Doutorado, Programa de Pós-Graduação em Engenharia Civil, Universidade Federal do Rio Grande do Sul.

Oliveira, J.B. 1999. Solos do estado de São Paulo: descrição das classes registradas no mapa pedológico. IAC, Campinas, 108p.

Paranhos, F.A.C., Fiori, A.P., Disperati, L., Lucchesi, C., Ciali, A. \& Lastoria, G. 2003. Avaliação Multitemporal das Perdas dos Solos na Bacia do Rio Taquarizinho através de SIG. Boletim Paranaense de Geociências, 52: 49-59.

Ponçano, W.L., Carneiro, C.D.R., Bistrichi, C.A., Almeida, F.F.M. \& Prandini, F.L. 1981. Mapa Geomorfológico do Estado de São Paulo. São Paulo, IPT-SP, v. 1, 94 p.

Risse, L.M., Nearing, M.A., Nicks, A.D. \& Laflen, J.M. 1993. Assessment of error in the universal soil loss equation. Soil Science Society of America Journal, 57(3): 825-833.

Ross, J.L.S. 2002. A morfogênese da bacia do rio Ribeira de Iguape e os sistemas ambientais. Revista GEOUSP Espaço e Tempo, São Paulo, No, 12. Available at:

http://www.geografia.fflch.usp.br/publicacoes /
Geousp/Geousp12/Geousp12_JurandyrRoss.htm

Ross, J.L.S. 2006a. Ecogeografia do Brasil: Subsídios para Planejamento Ambiental. São Paulo, Oficina de Texto, $208 \mathrm{p}$.

Ross, J.L.S. 2006b. Plano de conservação da bacia do alto Paraguai e o zoneamento ecológico-econômico para o Brasil. In: SIMPÓSIO DE GEOTECNOLOGIAS NO PANTANAL, 1, Anais..., Campo Grande, p. 11-15.

Stein, D.P., Donzelli, P.L., Gimenez, F.A., Ponçano, E.L. \& Lombardi, N.F. 1987. Potencial de Erosão Laminar, Natural e Antrópica na Bacia do Peixe-Parapanema. In: SIMPÓSIO NACIONAL DE CONTROLE DE EROSÃO, Anais..., Marília, São Paulo, ABGE/DAEE, v.4, p. 105-135.

Theodorovicz, A. \& Theodorovicz, A.M.G. 2007. Atlas geoambiental: subsídios ao planejamento territorial e à gestão ambiental da bacia hidrográfica do rio Ribeira de Iguape. $2^{\text {a }}$ ed. revisado, São Paulo, CPRM, 91p.

Tiwari, A.K., Risse, L.M. \& Nearing, M.A. 2000. Evaluation of WEPP and its comparison with USLE and RUSLE. Transactions of the American Society of Agricultural Engineers, 43: 1129-1135.

Ubierna, S.G., Martínez, M.A.C. \& Ibarra, J.M.N. USLE, RUSLE and WEPP models used in mining restored hillslopes. Uso de geotecnologias para mapeamento de áreas de riscos. In: CONGRESOS CIENTÍFICOS DE LA UNIVERSIDAD DE MURCIA, CONGRESO INTERNACIONAL SOBRE DESERTIFICACIÓN, ADVANCES IN SUTDIES ON DESERTIFICATION: CONTRIBUTIONS TO THE INTERNATIONAL CONFERENCE ON DESERTIFICATION. 2009, Murcia. Anais..., p.263266.

UFSC. Universidade Federal de Santa Catarina. Centro Universitário de Estudos e Pesquisas sobre Desastres. 2011. Atlas brasileiro de desastres naturais 1991 a 2011: volume Santa Catarina. Centro Universitário de Estudos e Pesquisas sobre Desastres, CEPED, UFSC, 80p.

Wischmeier, W.H. \& Smith, D.D. 1958. Rainfall energy and its relationship to soil loss. Transactions American Geophysical Union, 39(2): 285-291.

Wischmeier, W.H. \& Smith, D.D. 1965. Predicting rainfall-erosion losses from cropland east of the Rocky Mountains. AGR Handbook, U.S. Department of Agriculture, $282 \mathrm{p}$.

Wischmeier, W.H. \& Smith, D.D. 1978. Predicting rainfall erosion losses. A guide to conservation planning. Agriculture Handbook No. 537. United States Department of Agriculture, Washington, USA, 59p.

Yoder, D. C., Ketchem, A. J., Whittemore, D. A., Porter, J. P., Weesies, G. A. \& Renard, K. G. 1992. RUSLE user guide. Predicion soil erosion by water: a guide to conservation planning with the Revised Universal Soil Loss Equation (RUSLE). U.S. Dept. Agricultural Handbook., GPO n. 703.

Zuquette, L.V. \& Gandolfi, N. 2004. Cartografia Geotécnica. São Paulo, Oficina de Textos, 190p. 